\title{
The influence of Italian manners on politeness in England, 1550-1620
}

\author{
Jonathan Culpeper, Lancaster University, UK
}

This paper focuses on the influence of Italian conduct manuals, as translated into English, in the second half of the sixteenth century and early seventeenth century. It approaches this task in two ways. One is to trace the rise of the term manners, and also to examine the words with which it typically cohabited, thus giving a sense of the discourses of which it was a part. The analysis reveals a dramatic rise in usage of the term in the period 1550-1624, and its role in discourses to do with social regulation, negative evaluation and moralizing. The other is to undertake a detailed comparison between Della Casa's Galateo and Brown and Levinson (1987) in particular. The major finding here is the close similarity between the two. Along the way, the paper also airs some theoretical distinctions relating to notions of politeness, notably the distinction between firstand second-order politeness, and touches on some of the features of the social context of early modern England.

Keywords: civility, conduct manuals, Galateo, manners, politeness

\section{Introduction}

The study of politeness, with its focus on the use of language in social contexts, fits the research agenda of sociopragmatics. This point was argued by Leech (2003: 104; see also 1983). ${ }^{1}$ Sociopragmatics can most clearly be traced to the work of Leech (1983) and Thomas (e.g. 1981, 1983). It concerns the "more specific 'local' conditions on language use" (Leech 1983: 10), the "sociological interface of pragmatics" (Leech 1983: 10). Relatively recently, the area of historical sociopragmatics has taken shape. Culpeper (2010: 87) suggests that this area

concerns itself with any interaction between specific aspects of social context and particular historical language use that leads to pragmatic meanings. Its central focus is on language use in its situational context, and how those situational contexts engender norms which speakers engage or exploit for pragmatic purposes.

Given the connection between politeness and sociopragmatics, it is not surprising that there has been a parallel development in historical (im)politeness studies (e.g. Culpeper and Kádár 2010; Bax and Kádár 2012). This paper contributes to this particular area of study.

To the English present-day ear or eye, the notion of manners may seem somewhat remote, the stuff of crusty, overly-traditional aunts or uncles. It was not always so. According to the Oxford English Dictionary (OED), the first citation of the plural manners was 1225, and the earliest sense was "A person's habitual behaviour or conduct; morals". By the $15^{\text {th }}$ century, this sense seems to have extended beyond the individual to the behaviour of society: "The prevailing modes of life, the conditions of society; the customary rules of behaviour in a particular society, period, etc.". And by the late $16^{\text {th }}$ century, a closelyrelated more attitudinal, moralistic sense had developed: "Conduct in its moral aspect; morality; the moral code of a society." For the present-day politeness theorist, there are some obvious touchstones here. "Habitual behaviour" is considered a key focal point in many politeness theories. For example, Brown and Levinson (1987: 85) claim that their politeness strategies are partly designed to capture "routines", whilst Watts (e.g. 2003: 161) draws on Bourdieu's (1990) concept of "habitus" to describe his notion of "politic behaviour", "knowledge of which linguistic structures are expectable in a specific type of interaction in a specific social field". Furthermore, the relationship between habitual behaviours and morals has always been a close one. The OED notes that the senses above for manners are likely to have been shaped not only by the donor Anglo-Norman word manere, but also Latin mores, meaning "habits, morals", the word from which present-day English word morals is derived. Politeness theorists have been somewhat slow to appreciate the importance of morality in the context of politeness or impoliteness. Sell (1992) made some

\footnotetext{
${ }^{1}$ Here, the location of the field of study is being referred to. There is nothing to deny other perspectives - more linguistic, more sociological, more psychological, for example - being taken on politeness.
} 
early remarks, and recent discussions can be found in, for example, Culpeper (2011: 36-39, 59-62), Kádár and Haugh (2013: e.g. 147) and Haugh (2014: 172-9). Section 2 of this paper will have more to say about notions of politeness, especially so-called "politeness1" and "politeness2".

Around the middle of the 16th century, three important Italian conduct manuals on manners were published and translated into English. Although there were critical voices in some quarters, the social conditions of the late 16 th century and early 17 th century were conducive to these works in translation. I will briefly elaborate on these social conditions in section 3, but, more particularly, I will provide evidence of the extent and nature of the impact of these works through a study of the usage of the term manners, as tracked in Early English Books Online, a vast 1.2 billion word repository of early modern textual output. I will probe contemporary attitudes towards politeness by examining the collocates of manners. The most substantial part of this paper, section 4, focuses on one manual, Giovanni della Casa's Galateo (1558). This work has had tremendous impact across Europe and beyond. One reason for this is that it was more in tune with the civility needed by the up-and-coming middle-ranking city dweller, than the courtly model offered by, for example, Baldassarre Castiglione's more backward-looking Il Cortegiano (1528). I compare the Galateo with the politeness model outlined in Brown and Levinson (1987) in particular, but also some other modern politeness classics (e.g. Leech 1983). Given the differences in time, context and purpose, one might not expect to find many similarities. However, I will show that there are in fact many similarities, including some which are fundamental to classic present-day models, such as the notions of face-work, face threatening acts, deference and indirectness.

\section{Politeness: The academic view and the non-academic view}

A useful (if problematic) politeness distinction is that between so-called first-order politeness (politeness1) and second-order politeness (politeness2), a distinction that was proposed by Watts et al. ([1992] 2005). They write:

We take first-order politeness to correspond to the various ways in which polite behaviour is perceived and talked about by members of socio-cultural groups. It encompasses, in other words, commonsense notions of politeness. Second-order politeness, on the other hand, is a theoretical construct, a term within a theory of social behaviour and language usage. (2005:3)

Subsequently, researchers have discussed and developed the distinction in various ways (see especially Eelen 2001, but also, for example, Ehlich [1992] 2005; Watts 2003, Terkourafi 2011; Haugh 2012). Table 1 captures the features of each politeness type, as flagged up by these researchers.

Table 1. Characteristics of politeness1 and politeness2

\begin{tabular}{|l|l|}
\hline Politeness1 (P1) characteristics & Politeness2 (P2) characteristics \\
\hline Participant & Observer \\
\hline Non-academic (lay) & Academic \\
\hline Non-scientific & Scientific \\
\hline Use of 'lay' terms & Use of 'academic' terms \\
\hline Spontaneous, dynamic, contested & Planned, static, essentialist \\
\hline Evaluative & Non-evaluative \\
\hline Morally charged & Morally neutral \\
\hline Prescriptive & Descriptive \\
\hline
\end{tabular}

One of the problems in describing $\mathrm{P} 1$ or $\mathrm{P} 2$ is that practitioners do not orient to a single understanding or vision of what P1 or P2 might be. Studies do not display all the features of either P1 or P2 all of the time. Moreover, the distinction between P1 and P2 is not consistently maintained. For example, Watts (e.g. 2003), a practitioner of $\mathrm{P} 1$, includes the notion of "politic behaviour", which can hardly be described as a lay politeness term. Simiarly, practitioners of P2 do not always confine themselves to P2 features. For example, Brown and Levinson (1987), perhaps the archetype of P2, use both terms and notions, such as 'face' and 'offrecord', which do have a degree of lay person currency, at least in British culture, along with a host of terms which are widely used (e.g. 'polite', 'hint', 'direct'), albeit with definitions that may depart somewhat from lay understandings. Indeed, Eelen (2001: 75-6) argues that approaches whatever they claim to be are in fact invariably mixed. Where would conduct manuals fit in? They use 'lay' terms and are non-scientific, 
evaluative, morally charged and prescriptive. On the other hand, writers of such manuals are not participants in the interactions they talk about but more like observers of them.

A particular reason for airing this distinction here is that the interaction between $\mathrm{P} 1$ and $\mathrm{P} 2$ can been considered from an historical point of view, as indeed Terkourafi (2011) has done. I will pick out two pertinent points put forward by Terkourafi (2011) after a historical survey of courtesy, conduct, etiquette and netiquette manuals. The first is that P1 is partly characterised by a social regulatory role, and one which contributes to the reproduction of the social order that gave rise to them:

Politeness 1 norms effect social regulation inasmuch as they contribute to the reproduction of the social order that gave rise to them in the first place, legitimizing and consolidating it further. [...] Politeness 1 norms typically emanate from the upper classes and are a reflection of their power. This allows them to play a gate-keeping role which is central to the smooth operation of society - as we know it. Politeness 1 norms thus function as "carrott" and "stick" at one and the same time: abide by them, and you will go far; ignore them at your peril. (2011: 176)

The association with social regulation will be the strongest finding revealed in the corpus analyses for the term manners reported in section 3. As for the second point, recollect from Table 1 that prescriptive norms are associated with P1, and decriptive with P2. Do prescriptive norms follow descriptive, or is it something else?

Prescriptive norms [...] never materialize out of thin air; the process is never an entirely top-down or bottom-up one. Rather, prescriptive norms historically follow and reflect descriptive ones, while at the same time constraining future practices and so feeding back into the descriptive norms that gave rise to them in the first place. (2011: 176)

Given this intimate interconnection, Terkourafi (2011: 176) concludes that P1 and P2 "cannot be kept apart in principle, because they are intertwined from the outset". Section 4 looks at the specific connections between a P1 work and a P2 work.

\section{Italian manners manuals: The impact in England}

\subsection{The social context}

In the second half of the 16th century, three notable Italian conduct books or manuals on manners were translated into English in a space of twenty years.

\section{Table 1. Italian manners manuals and their English translations}

\begin{tabular}{|l|l|}
\hline Italian work & English translation \\
\hline Baldassarre Castiglione (1528) Il Cortegiano & Thomas Hoby (1561) The Courtyer \\
\hline $\begin{array}{l}\text { Giovanni della Casa (1558) Il Galateo [Galateo } \\
\text { Ovvero de' Costumi] }\end{array}$ & $\begin{array}{l}\text { Robert Peterson (1576) Galateo ... A treatise of the } \\
\text { maners and behauiours, it behoueth a man to vse } \\
\text { and eschewe, in his familiar conversation ... }\end{array}$ \\
\hline Stefano Guazzo (1574) La Civil Conversazione & George Pettie (1581) The Civil Conversation \\
\hline
\end{tabular}

The English social context offered a ripe market for these works, and much more so for Italian works than, say, Spanish, French or German. Italy was no threat to England, being fragmented into many states. It had considerable cultural prestige, not least because of its particularly strong associations with the Renaissance. Italy was the destination for the gentleman's "Grand Tour", and a possible venue for university. Elizabeth I spoke Italian fluently. More generally, England was witnessing a consolidation of the middle-ranks and concomitant urbanization (see Nevalainen and Raumolin-Brunberg 2003: Chapter 3, for a useful overview). Hitherto, a politeness concern was how to demonstrate one's rank thorough a display of courtly or courteous behaviour. Now, a pressing concern was how to get along with one's new neighbour. Thus, there was a shift from the virtues of courtesy to civility, what Bryson (1988) describes as the "science of sociability". Parallel to this shift was a shift from courtesy books to conduct manuals (Springarn 1914: xviii-xix). Of the three manuals listed in Table 1, Il Cortegiano, with its more courtly concerns, was not the book of the moment, even at court: 
To ioyne learnyng with cumlie exercises, Conto Balde|saer Castiglione in his booke, Cortegiane, doth trimlie teache: which booke, aduisedlie read, and diligentlie folowed, but one yeare at home in England, would do a yong ientleman more good, I wisse, then thrée yeares trauell abrode spent in Italie. And I meruell this booke, is no more read in the Court, than it is, seyng it is so well translated into English by a worthie Ientleman Syr Th. Hobbi who was many wayes well furnished with learnyng, and very expert in knowledge of diuers tonges. (Roger Ascham, The Scholemaster, 1570: 21)

Whilst conditions were ripe for these manuals, it should be noted things Italian were not always viewed positively. Consider this quotation from Shakespeare:

[Rosalind addressing Jacques. 'Gundello' = Gondola.]

Farewell Mounsieur Trauellor: looke you

lispe, and weare strange suites; disable all the benefits

of your owne Countrie: be out of loue with your

natiuitie, and almost chide God for making you that

countenance you are; or I will scarce thinke you haue

swam in a Gundello. (As You Like It Act IV. Sc.1 (F1))

Apparently, to mimic the fact that one has travelled to Italy requires a 'lispe' and the wearing of 'strange suites' - hardly a flattering perspective on Italian culture. A further quotation from Shakespeare suggests something of an inferiority complex:

[York to Gaunt about Richard II.]

The open eare of youth doth alwayes listen.

Report of fashions in proud Italy,

Whose manners still our tardie apish Nation

Limpes after in base imitation. (Richard II Act II. Sc. 1 (F1))

Furthermore, one important sector of society, the Puritans, were likely to feel uncomfortable with the new conduct manuals. This is because the manners of which they wrote concentrated rather more on superficial appearances, dissimulation and prevarication than the virtues behind such manners.

\subsection{The impact}

One way of getting a sense of the popularity of the notion of manners is to examine the frequencies of the term manners in the published output of the period. The total number of words in Early English Books Online (EEBO) of the period 1450 to 1724 is 320,620,846 words (7,962 texts). The frequencies of manners in 25-year periods are displayed in Figure 1. All figures and are extracted with the program CQPweb (Andrew Hardie, Lancaster University), as is the Figure itself.

Figure 1. The frequencies of the term manners in EEBO, 1450-1724 (Version 3, extracted via CQPweb)

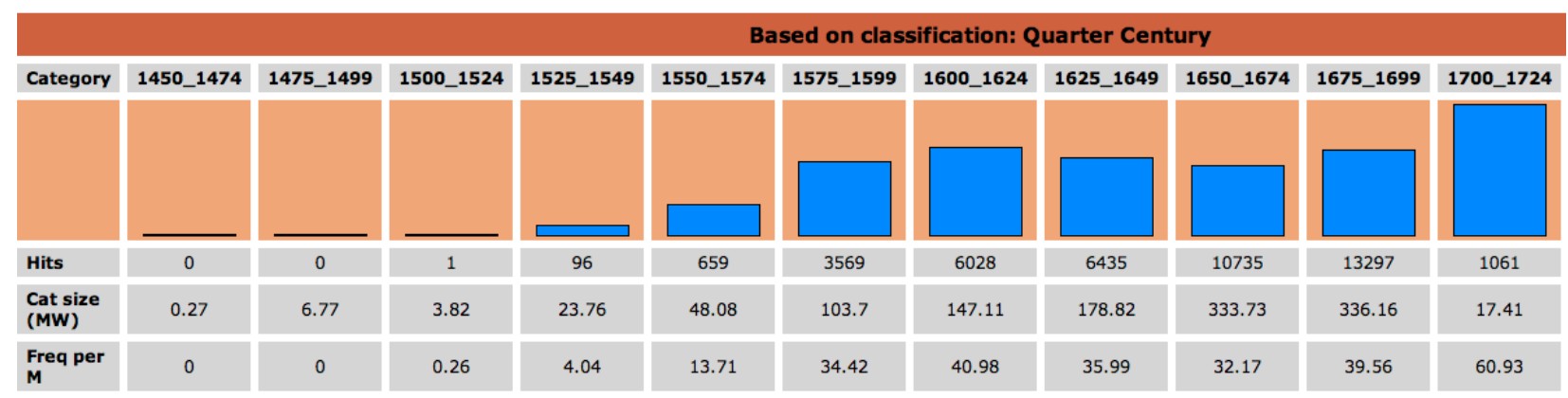

It is clearly not the case that the arrival of the three English translations triggered an interest in manners. The density of the term more than tripled between 1525-1549 and 1550-1574 from 4.04 to 13.71 instances per million; in other words, people were writing about manners before the first of the three translations 
mentioned above was published in 1561 . However, we should not make too much of this as the raw figure underlying $1525-1549$ is a mere 69 . Following this period, for three consecutive periods spanning 1550 to 1624 we see a massive increase in density, from 13.71 to 40.98 , and robust underlying frequencies (up to 6,028 by the end of that period). This is precisely the period when one might expect impact from the three translations. Before leaving Figure 1, note the remarkably high density of 60.93 for the period 1700-1724. This matches the kind of result reported in Jucker et al. (2012) for the term politeness. Both results support the idea of the 18th century as the Age of Politeness.

Thus far manners has been considered from a purely quantitative angle, but it is also possible to examine manners and its role in networks of meanings. Using (im)politeness metalanguage, such as manners, polite, rude, to explore politeness and impoliteness cultures and attitudes was the thrust of Culpeper (2009) and Jucker et al. (2012). Here, I will examine the collocates of manners - that is, the words which tends to co-occur with manners - in EEBO in the period 1550-1624, the period of particular relevance, as noted above. The total number of occurrences of manners was 10,256 (in 2,120 different texts) out of a total of 298,890,781 words. Again, I used the tool CQPweb. I set the window of occurrence at 5 words to left of the target and 5 to the right. ${ }^{2}$ The choice of statistic to use in calculating collocates is controversial. Simply calculating the likelihood that one word co-occurs with another using a probability measure may not be the best option, especially if we confine ourselves to examining the most likely combinations, as this does not give us a sense of how much of the data those combinations actually account for (i.e. the effect size). Consequently, I used the Log Ratio statistic available in CQPweb, and set the minimum frequency of both the target word manners and the collocate at $10 .^{3}$

Scrutinizing the top 50 collocates ordered according to Log Ratio, three dominant semantic groups can be identified, accounting for 41 of the 50 collocates, along with a rather more minor fourth group, containing 3 collocates. The words belonging to the individual groups are in bold.

NEGATIVE EVALUATION (17 collocates)

controllers, behaviours, fashions, nurture, customs, amending, dissolute, corrupt, corrupts, civility, gestures, Censors, reforming, behaviour, conditions, complexions, reform, corruption, amendment, Uncivil, amend, censuring, beastly, corrupting, depraved, framing, rude, correcting, correct, Conversation, dispositions, precepts, variable, corrupted, diversity, discipline, looseness, reformation, correction, diverse, sundry, lewd, dishonest, mend, perverse, honesty, corruptions, integrity, barbarous, disordered

SOCIAL REGULATION (13 collocates) controllers, behaviours, fashions, nurture, customs, amending, dissolute, corrupt, corrupts, civility, gestures, Censors, reforming, behaviour, conditions, complexions, reform, corruption, amendment, Uncivil, amend, censuring, beastly, corrupting, depraved, framing, rude, correcting, correct, Conversation, dispositions, precepts, variable, corrupted, diversity, discipline, looseness, reformation, correction, diverse, sundry, lewd, dishonest, mend, perverse, honesty, corruptions, integrity, barbarous, disordered

THE DOMAIN OF MANNERS (11 collocates) controllers, behaviours, fashions, nurture, customs, amending, dissolute, corrupt, corrupts, civility, gestures, Censors, reforming, behaviour, conditions, complexions, reform, corruption, amendment, Uncivil, amend, censuring, beastly, corrupting, depraved, framing, rude, correcting, correct, Conversation, dispositions, precepts, variable, corrupted, diversity, discipline, looseness, reformation, correction, diverse, sundry, lewd, dishonest, mend, perverse, honesty, corruptions, integrity, barbarous, disordered

\footnotetext{
${ }^{2}$ There is no strong consensus in the literature about what span should be used, though there seems to be a tendency to select 4 to the left and 4 to the right (McEnery and Hardie 2012: 129). I chose a slightly wider span in the basis of trial and error, that is, experimenting with different spans and choosing the one that gave the most results with the strongest relationship with the target item.

${ }^{3}$ Hardie comments in the help menu of CQPweb: "The Log Ratio statistic is a measurement of how big the difference is between the (relative)

frequency of the collocate alongside the node, and its (relative) frequency in the rest of the corpus or subcorpus. On its own, Log Ratio is very similar to the Mutual Information measure (both measure effect size). However, CQPweb combine Log Ratio with a statistical-significance filter. The collocate list is sorted by Log Ratio but filtered by Log-likelihood. Collocates are only included in the list if they are significant at the 5\% level ( $\mathrm{p}<$ $0.05)$, adjusted using Šidák correction. For your current collocation analysis, that means all collocates displayed have Log-likelihood of at least 20.19934. The use of a Log-likelihood filter means that it is not necessary to set minimum high values [...]".
} 
POSITIVE EVALUATION ( 3 collocates)

controllers, behaviours, fashions, nurture, customs, amending, dissolute, corrupt, corrupts, civility, gestures, Censors, reforming, behaviour, conditions, complexions, reform, corruption, amendment, Uncivil, amend, censuring, beastly, corrupting, depraved, framing, rude, correcting, correct, Conversation, dispositions, precepts, variable, corrupted, diversity, discipline, looseness, reformation, correction, diverse, sundry, lewd, dishonest, mend, perverse, honesty, corruptions, integrity, barbarous, disordered

In tune with P1 characteristics, evaluation is prominent; the largest group is negative evaluation. The focus is on enforcing manners to prevent behaviours which are dissolute, corrupt, uncivil, beastly, depraved, rude and so on. Note the moralising tone, and recollect the connection with P1, as mentioned in section 2 (and also the connection between manners and morality briefly mentioned in the first section of this paper). Reinforcing the point made in section 2 that P1 norms play an important role in social regulation, social regulation is a clear group. Manners are enforced by controllers and Censors as gold standards of behaviour, the attainment of which requires amending, correcting, censuring and so on. The domain of manners includes conversation and gestures, as well as behaviours, fashions and customs in general. The connection between manners and habitual behaviours, customs, was also briefly noted in the first section of this paper. Finally, we have a thinner group, positive evaluation. Of particular note here is the appearance of the collocate civility fairly early in the rank-ordered list (and also its antonym Uncivil). It is frequently used to denote a quality of manners (e.g. "civility of manners") or a similar quality (e.g. "manners and civility"). This, of course, provides evidence for the point made above that the rise of manners is closely linked to the rise of civility. Civility, we might note, seems to be the synonym of politeness that fits this period. In the following section, we will consider what it might encompass.

\section{Della Casa's Galateo (1558) and present-day politeness theories}

The durability and widespread impact of Della Casa's Galateo (1558) is remarkable, and this is why I focus on it here. It has been published in many languages, and new translations and editions still appear. The latest English translation by M.F. Rusnak appeared in 2013. Titles of translations and editions have been extremely variable. The title of the earliest publication is Galateo Ovvero de' Costumi, a rather literal translation of which would be "Galateo or about costumes". Costumi here has the overtones of fashions, habits, customs and morals. In Rusnak's translation, this has morphed into Galateo: Or, The Rules of Polite Behavior, a title which makes the connection with politeness clear (other editions have also made this connection explicit).

The author of Galateo, Giovanni della Casa (1503-1556), was an Italian archbishop, diplomat and writer. He wrote the Galateo between 1551 and 1555, its title being modelled on the name of Galeazzo Florimonte, Bishop of Sessa (Springarn 1914: 121). Della Casa was very well-connected: Cardinal Alessandro Farnese was his nephew, he had the patronage of Pope Paul III, and was even distantly related to Henry II of France (via his wife). Della Casa drew on this background for the Italian Galateo. In fact, he was not simply inspired by etiquette encountered in courtly circles, but, as Woodhouse (1994) argues, taking the opportunity for a satirical attack on the unpleasant behaviours he had encountered in his diplomatic career. Thus, those behaviours take on a more caricature-like quality. This aspect was lost by English translators with their "more serious and pragmatic attitudes" (Woodhouse 1994: 11). This includes the translation with which we are specifically concerned, namely, the first English translation of Robert Peterson 1576.

Moreover, it seems likely that Peterson was working as much if not more from the French translation as the Italian original (Springarn 1914: 122). Aside from general cultural and societal interest, as described in section 3, the success of Peterson's work in England was assisted by its affinities with an up-and-coming genre, the commonplace book. These were scrapbooks containing sayings, proverbs, poems, ballads, recipes, legal notes, and so on. The Galateo with its lists of conduct advice is a reasonable fit for such repositories of useful, often authoritative information, except for the fact that it is focussed on one topic area.

Peterson's title page describes the book as follows:

A treatise of the ma[n]ners and behauiours, it behoueth a man to vse and eschewe, in his familiar conuersation A worke very necessary \& profitable for all gentlemen, or other.

"Behoueth" lends a force of moral necessity, whilst "vse and eschewe" prepares the reader for a list of "do's" and "don't's" of the kind that is typical of much prescriptive literature. The target area of activity - 
"familiar conuersation" - suggests something of a departure from courtly courtesy literature, such as $I l$ Cortegiano, and perhaps angles for a somewhat broader audience. A target audience of "gentlemen" would seem the obvious choice: this was the group that had both the highest level of literacy and the money to buy books. However, the addition of "or other" on the title page seems to be a case of hedging bets. Peterson might have had his eye on social aspirers, the affluent middle-ranks who were trying to better themselves and ascend the social ladder. Indeed, the book's dedication was to Robert Dudley, Earl of Leicester, whose widespread reputation for elegance and savoir-faire made him an ideal target for the aspirational reader. On the face of it, then, the Galateo, in the guise of Peterson's translation, might seem light years away from modern politeness theories of the P2 kind, such as Brown and Levinson (1987), for example, which is based on much fieldwork and is theoretical and descriptive in approach. Nevertheless, the remaining paragraphs of this section will expose similarities and differences in more detail.

Consider this early statement:

$[\ldots]$ it behoues thee, to frame and order thy maners and doings, not according to thyne owne minde and fashion: but to please those, with whome thou lyuest, and after that sort direct thy doings: And this must be done by Discretion and Measure. (p.4)

There are several important echoes with modern politeness theories here, especially Brown and Levinson (1987). The basis of Brown and Levinson's facework is oriented towards 'managing' the other person's face (this is especially clear in the definitions of redressive face actions, including positive and negative face; cf. 1987: 69-70). This 'other' orientation is reflected here: "frame and order thy maners and doings, not according to thyne owne minde and fashion: but to please those, with whome thou lyuest". Concomitant with this is the "lip-service" quality of modern politeness theories: you are not saying what you really think, but saying something to "please" the other. Note also that this "pleasing" should not be done to excess but with "Discretion and Measure". Similarly, Brown and Levinson (1987: 74) outline the factors that deter the speaker from automatically selecting the most polite strategy as a kind of insurance policy.

The fact that linguistic politeness is pragmatic and strategic, rather than semantic and truth conditional, is emphasized by the classic modern theories. This can be clearly seen in the Galateo:

For if wee meete with a man, we neuer sawe before: with whome, vppon some occasion, it behoues vs to talke: without examining wel his worthines, most commonly, that wee may not offend in to litle, we giue him to much, and call him Gentleman, and otherwhile Sir, althoughe he be but some Souter or Barbar, or other suche stuffe: and all bycause he is appareled neate, somewhat gentleman lyke. [...] This vse and custome, though so fayre and gallant without, is altogether vaine within, and consisteth in semblance without effect, $\&$ in wordes without meaning. p.43

A fundamental of Brown and Levinson (1987) can be seen here in the Galateo:

We say then, that euery act that offendeth any the common senses, or ouerthwarteth a mans will and desire, or els presenteth to the Imagination and conceite, matters vnpleasaunt, \& that likewyse, which $\mathrm{y}^{\mathrm{e}}$ mynde doth abhorre, such things I say bee naught, and must not be vsed. (p.5)

The instruction not to use an "act that offendeth" is reminiscent of the avoidance of face threatening acts (FTAs). And there seem to be echoes of positive and negative politeness. Avoiding acts that "ouerthwarteth a mans will and desire" echoes negative politeness centring on the "want to be unimpeded" (Brown and Levinson 1987: 70); whilst avoiding acts which "presenteth to the Imagination and conceite, matters vnpleasaunt", echoes something of positive politeness, with its emphasis on maintaining "the positive selfimage that he [sic] claims for himself" (Brown and Levinson 1987: 70).

In the remainder of this section I will list specific similarities between the Galateo and Brown and Levinson (1987). A problem in doing this is that the Galateo presents relevant material through proscriptions/prescriptions, examples and anecdotes, all of which could not be repeated in full for reasons of space. I will proceed by offering a summary of the aspect in focus in italics, followed by some supporting quotation from the text (all italics within these quotations are as per the original). Then I will comment on parallels in modern politeness theory, especially Brown and Levinson (1987).

Aspects of positive politeness 
Avoid disparagement of the other, speak kindly. "Wee must not speake yll of other me , nor of their doings" (1576: 57). This is essence of positive politeness in Brown and Levinson's (1987) model. In Leech's (1983) model, this is obviously a matter of the Approbation Maxim.

Show others that we love them and value their love, greet them, treat others as friends. "They seeke to purchase $y^{t}$ which the benefit of mutuall conferrence may yeald them, \& that doe (as I weene) good will, honour, comforte and pleasure, or some other thing lyke vnto these: \& therfore we must neither say or doe the thing, that may giue any signe of litle louing or esteming them, we liue withall." (1576: 15-6). "he is pleasaunt and courteous: whose manners bee suche in his common behauiour, as practise to keepe, and maintaine him friendeship amongst them [...] So that it shalbe necessarie for a man, to vse him selfe to salute, to speake, and to answer after a gentle sorte, and to behaue him selfe wt all men so: as if hee were their countryman borne, \& of their olde acquaintance." (1576: 26). This is reflected in the intimacy aspect of positive politeness: "Positive-politeness utterances are used as a kind of metaphorical extension of intimacy, to imply common ground or sharing of wants to a limited extent even between strangers who perceive themselves, for the purposes of the interaction, as somehow similar" (Brown and Levinson 1987: 103).

Avoid topics that may give offence. "Againe, a man must not moue any question of matters that be to deepe $\&$ to subtile: because it is hardly vnderstoode of the moste. And a man must warely foresee, that the matter bee suche, as none of the company may blushe to heare it, or receaue any shame by the tale." (1576: 29). The idea of selecting 'safe topics' is discussed in the positive politeness strategy "Seek agreement" (Brown and Levinson 1987: 112). It is also apparent in one side of Leech's (1983) Agreement Maxim.

Don't question, contradict, rebuke, or correct. "For these quarelous contentions, bee foule and ill fauoured fashions for gentlemen to vse: and they get them ill will and displeasure of all men for it." (1576: 59). "To offer aduyse vnrequested: what is it els but to vaunt youre selfe wiser then he is, whom you do counsell." (1576: 60). "And they doe also make the like fault, $\mathrm{y}^{\mathrm{t}}$ take vppon them to reproue and correct mens faults, and to geue a definite sente ce in all things, and lay the lawe to all men." (1576: 61). This is echoed in a positive politeness strategy "Avoid disagreement", which involves such phenomena as token agreement, white lies and hedging opinions (Brown and Levinson 1987: 113-7). It is also apparent in one side of Leech's (1983) Agreement Maxim.

Share a fault. [Rather than say "you ar deceiued: Or, it is not true: Or, you know it not" (1576: 84)] "it doth well, to make the proper and peculiar fault of your friend, indifferent and common to you both: and first, to take one piece to your selfe, and then after, to blame and reproue him for it. VVee were deceined and failed muche: we forgot our selues yesterday to doe so. Although suche negligence \& errour, or what soeuer it be: be altogether his fault and not yours" (1576: 84). This is reflected in the positive politeness strategy "Impersonalize S and H" (Brown and Levinson 1987: 190-206).

Be interested in others. "They disquiet all the company, [those who go about] caring for them selues alone \& theyr owne matters" (1576: 21). This is reflected in the positive politeness strategy "Notice, attend to H (his interests, wants, needs, goals)" (Brown and Levinson 1987: 103-4).

\section{Aspects of negative politeness:}

Show respect, don't use ridicule. "Doe not allow, that a man should scorne or scoffe at any man, what so euerhe be: no not his very enimy, what displeasure so euer he beare him" (1576: 62). "And the Nature and effect of a scorne, is properly to take a contentation and pleasure to do another man shame and villany: thoughe it do our selues no good in the world. So that, good maner \& honesty, would vs beware we scorne no man in any case: wherin they be much to be blamed, that reproue men those blemishes they haue in their person" (1576: 63). "Our doings must rather beare a signe and shewe of reuerence, meekenes, \& respect toye company, in which we fellowship our selues" (1576: 23). "Neither must a man boaste of his Nobilitie, his Honour or riches: muche lesse vaunt of his witt" (1576: 37). "A man must neither embase, nor exalte him selfe to muche out of measure: but rather bury in sile $\sim$ ce some parte of his merits, then arrogate to muche vnto him." (1576: 38). This is echoed in a negative politeness strategy: "Give deference" (Brown and Levinson 1987: 178-87). It is also clearly reflected in Leech's (1983) Modesty Maxim. 
Use "sweete" talk. "You must accustome your selfe, to vse suche gentle and courtious speache to men, and so sweete, that it may haue no maner of bitter taste. And you shall rather say, I cannot tell how to say it: The say: you ar deceiued: Or, it is not true: Or, you know it not." (1576: 84). This is reflected in Brown and Levinson's (1987) Off-record superstrategy. It is also reflected in Leech's (1983) Tact Maxim and Hinting Strategy.

Aspects only covered by Leech (1983)

Don't talk too much or too little. "And I cannot gesse how it cometh to passe, that the veriest foole doth babble most: which ouer muche prattle, I would not haue a gentleman to vse, and specially, if his skill be but scant in the matter in talke: Not onely, bycause it is a hard matter: but, He must ru in many faults that talkes muche: but also, bycause a man weenes, that, He that talkes all the talke to him selfe, woulde (after a sorte) preferre him self aboue them all that heare him, as a Mayster would be aboue his scholers. And therfore, It is no good maner for a man to take vppo him a greater state, the doth become him." (1576: 93). "But, as ouer muche babble makes a ma weary: so doth ouer muche Silence procure as greate disliking. For, To vse silence in place vvhere other men talke to and fro: is in maner, asmuche a fault, as not to pay your share and scot as other men doe. And as speache is a meane to shewe men your minde, to whome you speake: so, doth Silence againe make me wene, you seke to be vnknowne" (1576: 94). Partly covered by Leech's (1983) Phatic Maxim: 'Avoid silence'. But modern theory does not explicitly cover face threat caused by talking too much.

Aspects of the Galateo not clearly covered by modern classic theories Avoid indelicate, vulgar, or coarse words. "Neither must a man, to make other men merie, speake foule and filthie wordes, nor make ilfauoured gestures, distorting his cou $\sim$ tenau $\sim$ ce, \& disfiguring his bodie" (1576: 70-1). "Nor we must not cou terfet our selues to be fooles \& vnsauorie doltes: but as tune \& occasio serueth, tell so $\sim$ e pretie tale or so e news, neuer heard of before, he $\mathrm{y}^{t}$ ca $\sim: \&$ he $y^{t}$ ca not, let him hold his peace. For, these be $y^{e}$ partes of $y^{e}$ wit: which, if they be sodain $\&$ prety, giue a proofe $\&$ a shew of $\mathrm{y}^{\mathrm{e}}$ quicknes of $\mathrm{y}^{\mathrm{e}}$ wit, \& the goodnes of $\mathrm{y}^{\mathrm{e}}$ maners of him $\mathrm{y}^{\mathrm{e}}$ speakes the $\sim$ : which thing doth verie much please men \& makes the $\sim$ our louers \& friends. But if they be otherwise, they woorke the $\sim$ a co $\sim$ trary effect" (1576: 71). Very briefly mentioned by Brown and Levinson (e.g. 1987: 138).

Guard against being too fastidious or sensitive. "[...] to bee to nyce or to deyntie: it may not be abiden, specially in men [...] they wilbe testy and frowarde, if you doe not quickly and readily slaute them" (1576: 27). There is no ready equivalent in modern theory, but this could perhaps be seen as a negative face strategy, since being too sensitive or fastidious restricts the communicative choices of the interlocutor.

Finally, we need to consider whether there are aspects of modern classic politeness theory not covered in the Galateo at all. What we do not find is conventional indirectness. This constitutes the first strategy listed under Brown and Levinson's negative politeness (1987: 132-45). It is also covered by Leech's (1983) Tact Maxim, the maxim that dominates his 1983 work. This absence is consistent with other studies. Culpeper and Demmen (2009) established that the key conventional indirectness output strategies of negative politeness - could you and can you requests - only emerge in the 19th century. Of course, we should remember that we are dealing with the English translation of a conduct manual reflecting the Italian context. Nevertheless, there are no translator marginal notes (of which there are quite a few generally in the book) indicating that that anything is awry, something which is consistent with there being no obvious lack.

\section{Conclusions}

English Translations of Italian conduct manuals appear towards the beginning of a steep rise in frequency of usage of the term manners, 1550-1624. Things Italian were in fashion, and fashion encompassed a wide range of practices, from what you wore to how you acted. The social context was ripe for Italian manuals, though not unequivocally. The collocates of the term manners reveal that it was part of discourse with three key features: social regulation, negative evaluation and moralizing. All of these have been claimed to be important characteristics of $\mathrm{P} 1$ politeness. Manners only had a handful of collocates relating to positive evaluation, but interestingly these included civility, rather than courtesy. The appearance of civility is consistent with a shift in politeness culture (or at least a shift in emphasis) involving the middling ranks of urban dwellers and their new "science of sociability". 
The Galateo seems to bear uncanny similarities to modern classic politeness theories, especially Brown and Levinson (1987). The 'other' orientation, the lip-service quality of pragmatic strategies, the notion of FTAs, positive politeness strategies, negative politeness strategies and off-recordness are all there. Only conventionally indirect negative politeness is not, something that is in tune with studies that attest its later development (e.g. Culpeper and Demmen 2009). Why do we find this similarity? Is this a case of P1 (Galateo) influencing P2 (Brown and Levinson 1987)? As a preliminary to addressing this question, we should remember, as noted in section 2, that P1 and P2 works are not totally distinct. Importantly in this case, both the writers of Galateo and of Brown and Levinson (1987), and of Leech (1983) for that matter, are more observers of than participants in the interactions they write about. Even putting this issue aside, we can only speculate about indirect influence. We know that the Galateo was hugely popular. It was read and referred to over centuries, and is highly likely to have influenced thinking about politeness - that is, politeness ideology - and thus practice. Maybe the frameworks that present-day researchers devised capture some of the influence that the Galateo has had. It is also worth remembering that, although I have not analysed the Italian, my analyses probably reflect something of the nature of the original Galateo and its Italian context. To this, we might note Kerbrat-Orecchioni's (2011: 151) paper arguing, though Brown and Levinson (1987) inspired analyses of French conduct manuals, that the "fundamental rules of politeness remain the same" over time. I would hesitate to say that such 'rules' are always the same. However, there may well be a case for saying that the countries in which the Galateo had notable impact - Italy, France, England and Spain - are likely to have had their early modern thinking about politeness shaped in a similar way.

One thing we can say with more certainty is that historical pragmaticists, such as Jucker (e.g. 2008, 2011, 2012) or Nevala (2004), are justified in applying Brown and Levinson (1987) to early modern English data. Further, and more specifically, Jucker's (e.g. 2012) idea of splitting the category of negative politeness into 'deference politeness' and 'non-imposition politeness', where conventionally indirect requests are sited, is supported. Researchers applying an undiscriminated category of negative politeness will fail to capture crucial changes within that category.

\section{References}

Ascham, Roger. 1570. The scholemaster or plaine and perfite way of teachyng children, to vnderstand, write, and speake, the Latin tong but specially purposed for the priuate brynging vp of youth in ientlemen and noble mens houses, and commodious also for all such, as haue forgot the Latin tonge [...]. STC (2nd ed.) / 832. Henry E. Huntington Library and Art Gallery.

Bax, M. and Kádár, D. 2012. Understanding Historical (Im)Politeness: Relational linguistic practice over time and across cultures. Benjamins Current Topics. Amsterdam, The Netherlands: John Benjamins

Bourdieu, Pierre. 1990. The Logic of Practice. Cambridge: Polity Press.

Brown, Penelope, and Stephen C. Levinson. 1987. Politeness. Some universals in language usage. Cambridge University Press: Cambridge.

Bryson, Anna. 1998. From Courtesy to Civility: Changing Codes of Conduct in Early Modern England. Oxford: Oxford University Press.

Culpeper, Jonathan. 2009. The Metalanguage of IMPOLITENESS: Explorations in the Oxford English Corpus. In Contemporary Corpus Linguistics, ed. by Paul Baker, 64-86. London: Continuum.

Culpeper, Jonathan. 2010. "Historical sociopragmatics". In Historical Pragmatics, ed. by Andreas H. Jucker, and Irma Taavistainen, 69-96. (Volume 5 of Handbooks of Pragmatics ed. by Wolfram Bublitz, Andreas H. Jucker and Klaus P. Schneider). Berlin: Mouton de Gruyter.

Culpeper, Jonathan. 2011. Impoliteness: Using Language to Cause Offence. Cambridge: Cambridge University Press.

Culpeper, Jonathan and Dániel Kádár. 2010. Historical (Im)Politeness Research. (Studies in Language and Communication, Vol. 65). Bern: Peter Lang.

Culpeper, Jonathan and Jane Demmen. 2011. "Nineteenth-century English politeness: Negative politeness, conventional indirect requests and the rise of the individual self". Journal of Historical Pragmatics $12(1 / 2): 49-81$.

Eelen, Gino. 2001. A Critique of Politeness Theories. Manchester: St. Jerome.

Ehlich, Konrad. 2005 [1992]. "On the historicity of politeness". In Politeness in Language: Studies in its History, Theory and Practice, ed. by Richard J. Watts, Sachiko Ide, and Konrad Ehlich, 71-107. Berlin and New York: Mouton de Gruyter. 
Haugh, Michael. 2012. "Epilogue: Deconstructing the first-second order distinction in face and politeness research. Special issue on 'Chinese face and im/politeness"'. Journal of Politeness Research 8 (1): 111-134.

Haugh, Michael. 2014. (Im)politeness Implicatures. Berlin: Mouton de Gruyter.

Jucker, Andreas H. 2008. Politeness in the history of English. In English Historical Linguistics 2006. Volume II: Lexical and Semantic Change. Selected Papers from the Fourteenth International Conference on English Historical Linguistics (ICEHL 14), Bergamo, 21-25 August 2006, ed. by Richard Dury, Maurizio Gotti and Marina Dossena, 3-29. Amsterdam/Philadelphia: John Benjamins.

Jucker, Andreas H. 2011. "Positive and negative face as descriptive categories in the history of English". Journal of Historical Pragmatics 12 (1-2): 178-197.

Jucker, Andreas H. 2012. "Changes in politeness cultures". In The Oxford Handbook of the History of English, ed. by Terttu Nevalainen, and Elizabeth C. Traugott, 422-433. Oxford: Oxford University Press.

Jucker, Andreas H., Irma Taavitsainen, and Gerold Schneider. 2012. "Semantic corpus trawling: Expressions of 'courtesy' and 'politeness' in the Helsinki Corpus". In Developing Corpus Methodology for Historical Pragmatics ed. by Carla Suhr, and Irma Taavitsainen. (Studies in Variation, Contacts and Change in English 11). Helsinki: Research Unit for Variation, Contacts and Change in English. Available online at http://www.helsinki.fi/varieng/journal/volumes/11/jucker taavitsainen schneider/

Kádár, Daniel, and Michael Haugh. 2013. Understanding Politeness. Cambridge, UK: Cambridge University Press.

Kerbrat-Orecchioni, Catherine. 2011. "From good manners to facework: Politeness variations and constants in France from the classic age to today". Journal of Historical Pragmatics 12 (1-2): 133-155.

Leech, Geoffrey N. 1983. Principles of Pragmatics. London: Longman.

Leech, Geoffrey N. 2003 Towards an anatomy of politeness in communication. International Journal of Pragmatics 14: 101-123.

Mcenery, Tony and Andrew Hardie. 2012. Corpus Linguistics. Cambridge, UK: Cambridge University Press.

Nevala, Minna. 2004. Address in Early English Correspondence. Its Forms and Socio-Pragmatic Functions. (Mémoires de la Société Néophilologique de Helsinki 64). Helsinki: Société Néophilologique.

Nevalainen, Terttu and Helena Raumolin-Brunberg. 2003. Historical Sociolinguistics. Cambridge, UK: Cambridge University Press.

Rusnak, M.F. (ed.). 2013. Galateo: The Rules of Polite Behavior. Chicago: University of Chicago Press.

Sell, Roger D. 2005 [1992]. "Literary texts and diachronic aspects of politeness". In Politeness in Language: Studies in its History, Theory and Practice, ed. by Richard J. Watts, Sachiko Ide, and Konrad Ehlich, 109-129. Berlin and New York: Mouton de Gruyter.

Spingarn, Joel E. (ed.). 1914. A Renaissance Courtesy-book: Galateo - Of Manners and Behaviours By Giavanni Della Casa. Boston: The Merrymount Press.

Terkourafi, Marina. 2011. "From Politeness1 to Politeness2: Tracking norms of im/politeness across time and space". Journal of Politeness Research 7: 159-185.

Thomas, Jenny. 1981. Pragmatic failure. University of Lancaster: Unpublished M.A. dissertation.

Thomas, Jenny. 1983. "Cross-cultural pragmatic failure". Applied Linguistics 4 (2): 91-112.

Watts, Richard J. 2003. Politeness. Cambridge: Cambridge University Press.

Watts, Richard J., Sachiko Ide, and Konrad Ehlich (eds). 2005 [1992]. Politeness in Language: Studies in its History, Theory and Practice. Berlin and New York: Mouton de Gruyter.

Woodhouse, John R. 1994. "The tradition of Della Casa's Galateo in English". In The Crisis of Courtesy: Studies in the Conduct-Book in Britain, 1600-1900, ed. by Jacques Carré. 11-16. Leiden: Brill. 